\title{
Nitrogen export from a boreal stream network following forest harvesting: seasonal nitrate removal and conservative export of organic forms
}

\author{
J. Schelker ${ }^{1,2}$, R. Sponseller ${ }^{3}$, E. Ring ${ }^{4}$, L. Högbom ${ }^{4}$, S. Löfgren ${ }^{5}$, and H. Laudon ${ }^{2}$ \\ ${ }^{1}$ Department of Limnology and Bio-Oceanography, University of Vienna, Vienna, Austria \\ ${ }^{2}$ Department of Forest Ecology and Management, Swedish University of Agricultural Sciences, Umeå, Sweden \\ ${ }^{3}$ Department of Ecology and Environmental Science, Umeå University, Umeå, Sweden \\ ${ }^{4}$ The Forestry Research Institute of Sweden (Skogforsk), Uppsala, Sweden \\ ${ }^{5}$ Department of Aquatic Sciences and Assessment, Swedish University of Agricultural Sciences, Uppsala, Sweden
}

Correspondence to: J. Schelker (jakob.schelker@univie.ac.at)

Received: 3 July 2015 - Published in Biogeosciences Discuss.: 3 August 2015

Revised: 17 November 2015 - Accepted: 26 November 2015 - Published: 14 January 2016

\begin{abstract}
Clear-cutting is today the primary driver of largescale forest disturbance in boreal regions of Fennoscandia. Among the major environmental concerns of this practice for surface waters is the increased mobilization of nutrients, such as dissolved inorganic nitrogen (DIN) into streams. But while DIN loading to first-order streams following forest harvest has been previously described, the downstream fate and impact of these inputs is not well understood. We evaluated the downstream fate of DIN and dissolved organic nitrogen (DON) inputs in a boreal landscape that has been altered by forest harvests over a 10-year period. The small first-order streams indicated substantial leaching of DIN, primarily as nitrate $\left(\mathrm{NO}_{3}^{-}\right)$in response to harvests with $\mathrm{NO}_{3}^{-}$concentrations increasing by $\sim 15$-fold. $\mathrm{NO}_{3}^{-}$concentrations at two sampling stations further downstream in the network were strongly seasonal and increased significantly in response to harvesting at the mid-sized stream, but not at the larger stream. DIN removal efficiency, $E_{\mathrm{r}}$, calculated as the percentage of "forestry derived" DIN that was retained within the stream network based on a mass-balance model was highest during the snowmelt season followed by the growing season, but declined continuously throughout the dormant season. In contrast, export of DON from the landscape indicated little removal and was essentially conservative. Overall, net removal of DIN between 2008 and 2011 accounted for $\sim 65 \%$ of the total DIN mass exported from harvested patches distributed across the landscape. These results high-
\end{abstract}

light the capacity of nitrogen-limited boreal stream networks to buffer DIN mobilization that arises from multiple clearcuts within this landscape. Further, these findings shed light on the potential impact of anticipated measures to increase forest yields of boreal forests, such as increased fertilization and shorter forest rotations, which may increase the pressure on boreal surface waters in the future.

\section{Introduction}

Decades of research have shown that disturbance of forest ecosystems can lead to increased losses of nitrogen $(\mathrm{N})$, especially as inorganic $\mathrm{N}$ from land. (Vitousek et al., 1979; Likens and Bormann, 1995; Aber et al., 2002; Houlton et al., 2003), with potentially negative consequences for water quality in streams and rivers (Martin et al., 2000). Perhaps the clearest demonstrations of how forest disturbance influences terrestrial nutrient mobilization have used experimental harvests in small catchments to document changes in stream chemistry relative to undisturbed controls (Likens et al., 1970; Swank and Vose, 1997). While the magnitude and duration of response to harvest varies among studies (Binkley and Brown, 1993; Kreutzweiser et al., 2008), most have documented increases in stream-water nitrate $\left(\mathrm{NO}_{3}^{-}\right)$concentrations. Such responses reflect the loss of plant nutrient demand (Boring et al., 1981), accelerated rates of soil $\mathrm{N}$ mineralization and 
nitrification (Holmes and Zak, 1999), and increases in hydrologic flux within the catchment (Hornbeck et al., 1997; Andréassian, 2004). By design, the majority of this research has addressed responses to forest disturbance at small spatial scales (e.g., catchments of first-order streams) and few studies have explored how localized increases in nutrient concentration are translated downstream within fluvial networks (Bernhardt et al., 2003).

Whereas several recent studies have addressed the removal of inorganic $\mathrm{N}$ within river networks (Helton et al., 2011; Wollheim et al., 2006; Worrall et al., 2012; Alexander et al., 2009), little has been done to investigate these processes in boreal landscapes subject to widespread and active forest management. A clearer understanding of how the enrichment of headwater environments through forestry is expressed at larger spatial scales (Futter et al., 2010) is important if policy makers are to consider the broader biogeochemical implications of forest management.

The degree to which surplus $\mathrm{NO}_{3}^{-}$derived from forest disturbance is delivered to downstream receiving systems is determined by the balance between hydrologic transport and biological demand within multiple habitats at the terrestrialaquatic interface (McClain et al., 2003; Seitzinger et al., 2006). For example, when forest harvesting leaves riparian buffer zones intact, plant nutrient uptake, immobilization by soil heterotrophs, and denitrification in streamside habitats can together greatly reduce the delivery of $\mathrm{NO}_{3}^{-}$to streams (Laurén et al., 2005). The efficiency of riparian $\mathrm{NO}_{3}^{-}$removal varies among studies (Ranalli and Macalady, 2010; Weller et al., 2011), and is determined, in large part, by topographic and soil properties that influence the rates and efficacy of denitrification through effects on hydrologic transport (Ocampo et al., 2006), soil/sediment redox conditions (Pinay et al., 2000), and depth of groundwater flow pathways relative to biogeochemically active soil layers (Vidon and Hill, 2004; Groffman et al., 2002). Riparian N retention efficiency, and the mechanisms responsible, may also vary in response to changes in plant demand (Sabater et al., 2000), availability of labile carbon (C) to soil and sediment microbes (Starr and Gillham, 1993), and hydrologic forcing during floods that overwhelms biotic potential (Hill, 1993).

Where forest harvests extend to channel margins, or when retention of $\mathrm{NO}_{3}^{-}$in riparian buffer zones is poor, surplus $\mathrm{NO}_{3}^{-}$derived from disturbance is delivered directly to streams. Rates of nutrient uptake in streams and hyporheic zones can be rapid (Mulholland et al., 2008) and uptake of $\mathrm{NO}_{3}^{-}$in headwater environments may reduce watershed exports in response to forest disturbance (Bernhardt et al., 2003; Riscassi and Scanlon, 2009). $\mathrm{NO}_{3}^{-}$removal in streams may be linked to immobilization by autotrophic and heterotrophic microbes, as well as to denitrification in hyporheic sediments (Harvey et al., 2013; Mulholland et al., 2008). The efficiency of this $\mathrm{NO}_{3}^{-}$removal (i.e., the percentage removed per unit stream length) is determined by the strength of this biological demand relative to nutrient availability (Mulholland et al., 2008), and is further constrained by hydrologic factors that govern residence times in biological active zones (Wollheim et al., 2006). As a result, removal efficiency tends to be the lowest during periods of high flow and/or $\mathrm{NO}_{3}^{-}$flux (Alexander et al., 2009; Scanlon et al., 2010). Biological activity and associated nutrient demand in streams is strongly influenced by a variety of habitat factors (e.g., incident light, temperature, and organic matter availability) that vary seasonally (Roberts and Mulholland, 2007; Valett et al., 2008). These factors are also modified by disturbance in the surrounding landscape (e.g., through loss of canopy cover), with the result that in-stream retention of excess $\mathrm{NO}_{3}^{-}$may itself change in response to harvesting (Bernhardt et al., 2003; Sabater et al., 2000).

In this paper we explore the potential for fluvial networks to remove $\mathrm{NO}_{3}^{-}$derived from forest harvesting in a boreal landscape in northern Sweden, where $\mathrm{N}$ limitation of terrestrial (Högberg et al., 2006) and aquatic (Jansson et al., 2001) productivity is common. We compiled 10 years of data on clear-cuts performed in this landscape with 8 years of temporally coinciding stream chemistry data from a third-order stream network. The network includes a replicated paired catchment harvesting experiment in the headwaters, plus several additional harvests (Fig. 1). Enhanced $\mathrm{NO}_{3}^{-}$loading to headwater streams (first order) as a result of forest clearcutting has been reported previously for this site (Löfgren et al., 2009). Thus, the study design and history of research in this landscape provide a unique opportunity to explore the downstream implication of forest harvesting. We use a simple modeling approach to ask (i) whether and how $\mathrm{NO}_{3}^{-}$exported from recent $(<10$ years) clear-cuts influences water chemistry downstream within the same drainage system, and (ii) to what degree downstream patterns in nutrient concentration arise from simple dilution of upstream inputs vs. biological uptake and retention in stream and riparian habitats.

\section{Methods}

\subsection{Study site}

This study was performed in the Balsjö paired catchment experiment located in the boreal forest of northern Sweden $\left(64^{\circ} 1^{\prime} 37^{\prime \prime} \mathrm{N}, 18^{\circ} 55^{\prime} 43^{\prime \prime} \mathrm{E}\right)$ (Löfgren et al., 2009). The experiment consists of four first-order streams of which two were clear-cut harvested (clear-cuts: CC-4 and NO-5; controls: RS-3 and NR-7) in 2006 and two third-order downstream sites of different size (BA-1, size: $22.9 \mathrm{~km}^{2}$ and BA2, size: $8.9 \mathrm{~km}^{2}$; Fig. 1). Clear-cutting at CC-4 was carried out to the stream bank, whereas a small, $\sim 10 \mathrm{~m}$ wide, discontinuous riparian buffer was left intact on both sides of the stream at NO-5. All clear-cuts in the network were performed as final fellings for commercial purposes following environmental considerations according to the Swedish Forestry Act, 


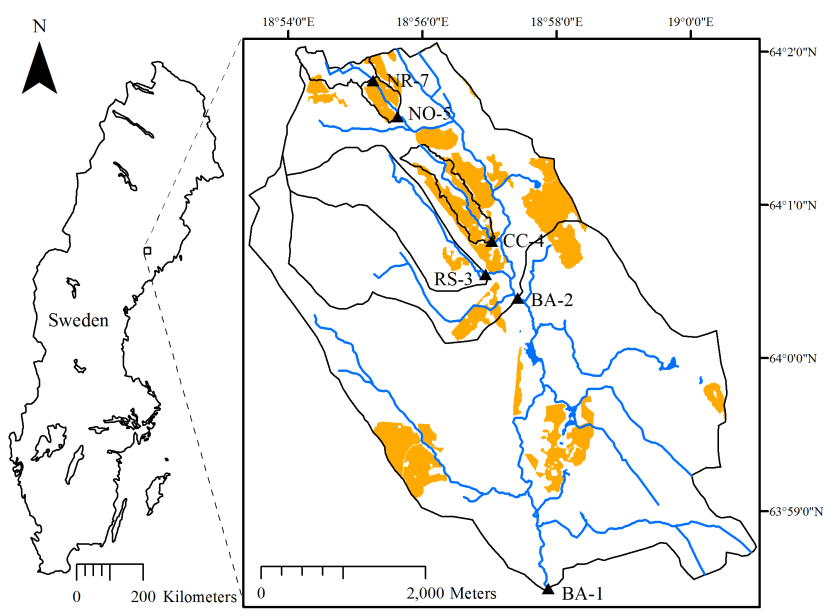

Figure 1. The Balsjö paired catchment experiment including the catchments RS-3, CC-4, NO-5, and NR-7, as well as the two downstream sites BA-2 and BA-1 that integrate the larger $22.9 \mathrm{~km}^{2}$ Balsjö Stream Network. Areas harvested during 2001-2011 are shown as orange. Solid blue lines represent the stream network; solid blue areas show ponds with open water. Solid black lines indicate the catchment boundaries, black pyramids the location of water sampling.

interpreted and applied by the forest owner. Thus, leaving small $(5-10 \mathrm{~m})$ buffer zones along headwater streams is considered common practice. However, field observations also showed substantial disturbance of riparian zones by forestry machinery crossing streams and by wind throw within narrow stream corridors. Together these impacts likely limit the effect of the environmental considerations for nutrient retention.

The Balsjö catchment is underlain by highly compacted till layers that have generally low hydraulic conductivities. Runoff generation is thus primarily from shallow saturated soil water entering streams laterally (Bishop et al., 2004; Schelker et al., 2013a). Thus, and in contrast to other stream systems, contributions from deep groundwater sources are thought to be minor at the spatial scale of this third-order stream network (Schelker et al., 2014).

\subsection{Stream water chemistry}

Concentrations of $\mathrm{NO}_{3}^{-}$, ammonium $\left(\mathrm{NH}_{4}^{+}\right)$and dissolved organic nitrogen (DON), chloride $(\mathrm{Cl})$, and dissolved silica (Si) were determined from unfiltered stream water samples. As fractions of particulate organic matter are generally very low in this landscape ( $<0.6 \%$; see Laudon et al., 2011), we consider samples to represent dissolved solute concentrations. Samples were collected between 2004 and 2012 at 1 to 2 week intervals during spring, summer, and fall, and at 4 week intervals during winter low flow. Samples were frozen within 1-2 days after collection and analyzed using colorimetric methods at a SWEDAC accredited laboratory according to method SS-EN ISO 13395:1996 for $\mathrm{NO}_{3}^{-}$(sulfanilamide method after cadmium reduction), according to Bran \& Luebbe Method G-171-96 Rev. 1 (Phenate method) for $\mathrm{NH}_{4}^{+}$, and method SS-EN 12260:2004 for total N (combustion to nitrous oxide followed by chemiluminescence detection) (Löfgren et al., 2009). Thus, reported concentrations of $\mathrm{NO}_{3}^{-}$equal the sum of nitrate and nitrite expressed as mass of $\mathrm{N}\left(\mu \mathrm{g} \mathrm{N} \mathrm{L}^{-1}\right)$; DIN concentrations were calculated as the sum of $\mathrm{NO}_{3}^{-}$and $\mathrm{NH}_{4}^{+}$; concentrations of DON as total $\mathrm{N}$ minus DIN. Analysis of $\mathrm{Cl}$ and $\mathrm{Si}$ are described in previous work (Schelker et al., 2014). Analysis uncertainty for $\mathrm{NO}_{3}^{-}$ were $5 \%$ for the concentrations range of $1-100 \mu \mathrm{g} \mathrm{L}^{-1}$ and $4 \%$ for $100-1000 \mu \mathrm{g} \mathrm{L}^{-1}$; uncertainties for $\mathrm{NH}_{4}^{+}$were reported as $14 \%$ for $3-20 \mu \mathrm{L} \mathrm{L}^{-1}$ and $8 \%$ for $20-100 \mu \mathrm{g} \mathrm{L}-1$. Uncertainties for total $\mathrm{N}$ were $14 \%$ for $50-1000 \mu \mathrm{g} \mathrm{L}^{-1}$ and $8 \%$ for $1-5 \mathrm{mg} \mathrm{L}^{-1}$.

\subsection{Mixing model}

We used a mixing model to represent the landscape mass balance for $\mathrm{NO}_{3}^{-}$and DON. This model assumes conservative mixing as well as conservative mass transport of water and solutes from two landscape end-members (EMs): clearcuts and control forests (following Schelker et al., 2014). The chemistry at downstream stations (BA-1 and BA-2) can then be predicted from the simple mixing of the hydro-chemical signal from the upstream EMs. The percentage of clear-cut area of each sub-catchment was derived from high-resolution satellite images supplied by the Swedish Forest Agency combined with local ground truthing (see Schelker et al., 2014, for a full description). These data comprise all clear-cuts from the past 10 years (2001-2011; see also Fig. 1). Similar to earlier work, we considered harvests prior to this period to have a negligible effect, due to their low spatial extent in the watershed (Schelker et al., 2014), and studies elsewhere in the boreal zone that suggest a 10-year time window within clear-cutting is likely to affect DIN exports (e.g., Palviainen et al., 2010). The remaining area of the catchment was assumed to constitute entirely uncut forest.

The concentration at the downstream locations BA-1 and BA-2 $\left(C_{\text {modeled }}\right.$, in $\left.\mu \mathrm{g} \mathrm{L}^{-1}\right)$ for each time step was modeled using the area-specific mass export:

$C_{\text {modeled }}=\left(M_{\text {harvest }} A_{\text {harvest }}+M_{\text {control }} A_{\text {control }}\right) Q_{\text {out }}^{-1}$

where $Q_{\text {out }}$ is the specific discharge ( $\mathrm{mm}$ ) at the downstream site and $M_{i}\left(\mu \mathrm{g} \mathrm{m}^{-2}\right)$ the solute mass export for the site $i$ ( $i=$ harvest, control). $M_{i}$ was calculated as $M_{i}=Q_{i} C_{i}$, with $C_{i}\left(\mu \mathrm{g} \mathrm{L}^{-1}\right)$ being the solute concentration and $Q_{i}(\mathrm{~mm})$ being the discharge. $A_{i}(-)$ was the fraction of the total area that was harvested or acts as a control for the site $i$. This mass-balance model simulates the contributions of clear-cuts versus control forests to downstream sites by considering changes in solute concentrations and water discharge. When measured and modeled concentration are plotted against each other for each sampling date, comparatively higher modeled 
concentrations (above the $1: 1$ line) indicate a mass loss of the solute during transport downstream (and vice versa) assuming conservative mass transport and mixing.

A $100 \%$ harvested catchment did not exist in Balsjö and N leakage into first-order streams following clear-cutting may vary depending on local factors, such as the presence of riparian forest buffers (Laurén et al., 2005), and was also observed to differ between the two harvested sites in Balsjö (Löfgren et al., 2009). Thus, we calculated $C_{\text {harvest }}\left(\mu \mathrm{g} \mathrm{L}{ }^{-1}\right.$ ) in Eq. (1) for each time step as the average concentration of CC-4 and the NO-5 northern catchment, each scaled to $100 \%$ harvest using a scaling equation. Assuming a linear increase of harvesting effects, this equation extrapolates the difference between observed concentration $\left(C_{\mathrm{obs}, j}\right.$, in $\mu \mathrm{g} \mathrm{\textrm {L } ^ { - 1 }}$ with $j=\mathrm{CC}-4$ or NO-5) and the concentration of the control forest $\mathrm{EM}, C_{\text {control }}\left(\mu \mathrm{g} \mathrm{L}^{-1}\right)$, to $100 \%$ harvest.

$C_{\text {harvest }, j}=C_{\text {control }}+\left(C_{\text {obs }, j}-C_{\text {control }}\right) d_{j}$

The conversion factor, $d_{j}$, was defined as $d_{j}=1 / A_{j}$, that is, the reciprocal of the fraction of the area harvested $\left(A_{j}\right)$ for the site $j$. Furthermore, $C_{\text {control }}$, the concentration representing the control forest EM, was calculated as the average concentration of the two forested reference sites RS-3 and NR-7, that differ in terms of stand age and peatland coverage (Schelker et al., 2014; Löfgren et al., 2009).

Stream discharge $(Q$, in $\mathrm{mm})$ for each EM was determined using approaches described previously (Schelker et al., 2014). In short, $Q$ was derived from the water level time series that were recorded hourly by two Trutrack WTH staff loggers at the sites NR-7, NO-5, CC-4, and BA-1 from which discharge was calculated using well-established rating curves at V-notch weirs (Schelker et al., 2012). $Q_{\text {harvest }}$ was calculated as the difference between $Q_{\mathrm{NR}-7}$ and $Q_{\mathrm{NO}-5}$, a nested downstream catchment with $88 \%$ harvest that is assumed to represent a $100 \%$ harvest. $Q_{\text {control was set equal to } Q_{\mathrm{NR}-7} \text {. }}$

The definitions of $Q$ have been validated in an earlier application of the mixing model, where it was shown that daily $Q$ at BA-1 was modeled reasonably well and with minimal bias using the above assumptions (relationship of modeled vs. measured $Q: r^{2}=0.77$, slope $=1.01, y$ intercept $=0.0001$; see Schelker et al., 2014). To further evaluate the representativeness and robustness of the mixing model, the two conservative tracers, $\mathrm{Cl}$ and $\mathrm{Si}$ were also modeled. A comparison of the modeled vs. measured concentrations (Fig. 2a to d) revealed modeled concentrations to scatter closely around the $1: 1$ lines with a slightly better fit for BA2 than for BA-1 and no indications of systematic deviations. These results suggest the validity of the model assumptions for these two conservative tracers.

\subsection{Additional calculations}

Inorganic nitrogen removal efficiency $\left(E_{\mathrm{r}}\right.$, in \%) was calculated as the difference between modeled and measured DIN concentrations divided by the modeled concentration. Thus,
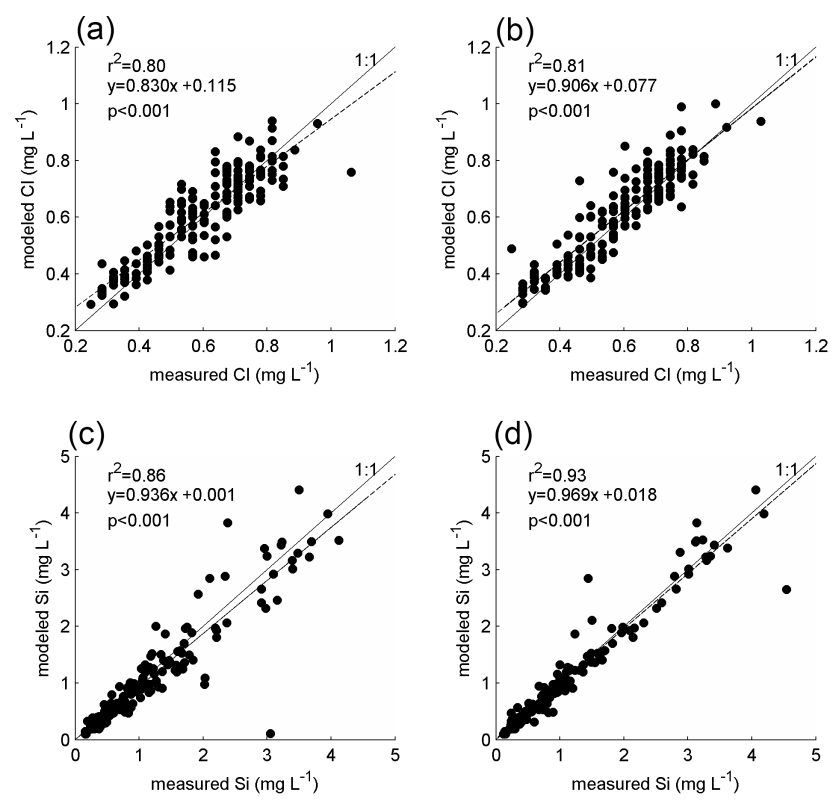

Figure 2. Comparison of modeled and measured $\mathrm{Cl}$ and $\mathrm{Si}$ concentrations for BA-1 (a and c) and BA-2 (b and d).

$E_{\mathrm{r}}$ equals the percentage of DIN that was removed between harvested areas and downstream sampling stations during transport, and this value approaches zero when DIN behaves conservatively in the landscape. If differences between measured and modeled [DIN] were $<0, E_{\mathrm{r}}$ was set to zero.

Annual export of DIN and $\mathrm{NO}_{3}^{-}$was calculated for each sampling station and year. Solute concentrations between the sampling occasions were interpolated linearly. Daily loads were calculated as the product of concentration and stream discharge and are expressed per unit catchment area. In addition, to compare against the observed DIN and $\mathrm{NO}_{3}^{-}$export, modeled estimates of annual export were calculated for BA-1 and BA-2 assuming conservative transport of $\mathrm{N}$ from upstream sources. To further infer seasonal effects on $\mathrm{N}$ exports, seasons were defined as following: dormant season from November to the end of March, snowmelt season from April to the end of May, and growing season from June to the end of October of each year.

To evaluate whether in-stream processes could be responsible for the modeled removal of $\mathrm{N}$ in the landscape, we calculated net areal uptakes rates $\left(U ; \mu \mathrm{g} \mathrm{N} \mathrm{m}^{-2} \mathrm{~min}^{-1}\right)$ for DIN as the difference between modeled and the measured mass fluxes of DIN divided by the total upstream stream surface area. Stream surface areas (Table 1) were estimated by linear interpolation from known transects within the network combined with a manual analysis of high-resolution air photographs. These coarse estimates of $U$ thus represent the net removal of DIN in streams that would be required to achieve mass conservation (an even mass balance) in the landscape mixing model. Thus, these estimates also represent maximum potential rates as they assume that all uptake would 
Table 1. Catchment characteristics of the six nested Balsjö catchments.

\begin{tabular}{|c|c|c|c|c|c|c|c|c|c|}
\hline \multirow[t]{2}{*}{$\begin{array}{l}\text { Site } \\
\text { name }\end{array}$} & \multirow[t]{2}{*}{$\begin{array}{l}\text { Short } \\
\text { name }\end{array}$} & \multirow{2}{*}{$\begin{array}{r}\text { Catchment } \\
\text { area } \\
\text { (ha) }\end{array}$} & \multicolumn{2}{|c|}{$\begin{array}{l}\text { Proportion } \\
\text { clear-cut* }^{*} \\
2004 ; 2011\end{array}$} & \multirow{2}{*}{$\begin{array}{r}\text { Wetland } \\
\text { area } \\
\text { (ha) }\end{array}$} & \multirow{2}{*}{$\begin{array}{r}\text { Total } \\
\text { stream } \\
\text { Length } \\
(\mathrm{m})\end{array}$} & \multirow{2}{*}{$\begin{array}{l}\text { Lake } \\
\text { area* }^{*} \\
\left(\mathrm{~m}^{2}\right)\end{array}$} & \multirow{2}{*}{$\begin{array}{r}\text { Stream } \\
\text { surface } \\
\text { area } \\
\left(\mathrm{m}^{2}\right)\end{array}$} & \multirow{2}{*}{$\begin{array}{r}\text { Total } \\
\text { water } \\
\text { area } \\
\left(\mathrm{m}^{2}\right)\end{array}$} \\
\hline & & & & {$[\%]$} & & & & & \\
\hline Balån River 1 outlet & BA-1 & 2291 & 2 & 11 & 337 & 37521 & 87829 & 185738 & 273567 \\
\hline Balån River 2 & BA-2 & 868 & 5 & 18 & 88 & 15754 & 6590 & 19249 & 25839 \\
\hline Southern reference & RS-3 & 156 & 0 & 3 & 4 & 2195 & 0 & 2195 & 2195 \\
\hline Southern clear-cut & $\mathrm{CC}-4$ & 41 & 0 & 56 & 3 & 1650 & 0 & 660 & 660 \\
\hline Northern catchment & NO-5 & 40 & 0 & 33 & 5 & 1386 & 0 & 554 & 554 \\
\hline Northern reference & NR-7 & 24 & 0 & 16 & 4 & 835 & 0 & 334 & 334 \\
\hline
\end{tabular}

* Estimated from satellite data.

occur within the stream boundaries and not within adjacent riparian soils.

Statistical analysis of differences in measured concentrations before and after clear-cutting in the same stream, as well as between sampling sites were performed as two sample Student's $t$ tests, accounting for unequal variance. If data were not normally distributed, a Mann-Whitney rank sum test was used instead for pairwise comparisons.

\section{Results}

\subsection{DIN and DON responses to harvest}

Forest harvesting increased DIN mobilization into firstorder streams. Average concentrations of $\mathrm{NO}_{3}^{-}( \pm \mathrm{SD})$ at the CC-4 catchment increased significantly $(p<0.001)$ by more than 15-fold from $15.6( \pm 10.9 ; n=62) \mu \mathrm{g} \mathrm{NL}^{-1}$ before harvest to $261.0( \pm 170.4 ; n=151) \mu \mathrm{g} \mathrm{NL}^{-1}$ after the treatment (Fig. 3b). In the NO-5 catchment, the response to harvests was less pronounced but also significant $\left(11.4( \pm 8.6 ; n=62) \mu \mathrm{g} \mathrm{N} \mathrm{L}^{-1}\right.$ before harvest and 25.9 $( \pm 35.3 ; n=151) \mu \mathrm{g} \mathrm{N} \mathrm{L}^{-1}$ after; $\left.p<0.001\right)$. Average concentrations at the NR-7 control stream were $27.6( \pm 20.5$; $n=60) \mu \mathrm{g} \mathrm{N} \mathrm{L}^{-1}$ in the early period of 2004 to 2006, and did not change significantly in the later period from 2007 to $2012\left(23.1( \pm 22.2 ; n=151) \mu \mathrm{g} \mathrm{N} \mathrm{L}^{-1}\right)$. At the RS-3 control stream $\mathrm{NO}_{3}^{-}$concentrations were also low, $12.3( \pm 9.2 ; n=49) \mu \mathrm{g} \mathrm{NL}^{-1}$ in the early period, but decreased significantly to $5.8( \pm 7.5 ; n=151) \mu \mathrm{g} \mathrm{N} \mathrm{L}^{-1}$ during 2007-2012. Similarly, concentrations of $\mathrm{NH}_{4}^{+}$and DON increased in the CC-4 catchment following harvesting (Fig. 3c and d) from $14.7( \pm 6.4 ; n=30) \mu \mathrm{g} \mathrm{N} \mathrm{L}^{-1}$ to $61.8( \pm 79.9$; $n=151) \mu \mathrm{g} \mathrm{N} \mathrm{L}^{-1}$ and from $324( \pm 108 ; n=30) \mu \mathrm{g} \mathrm{NL}^{-1}$ to $484( \pm 239 ; n=151) \mu \mathrm{g} \mathrm{N} \mathrm{L}{ }^{-1}$ for $\mathrm{NH}_{4}^{+}$and DON, respectively. At the reference sites, $\mathrm{NH}_{4}^{+}$and DON remained at similar levels or decreased in the period after harvesting (Fig. $3 \mathrm{c}$ and d). In addition to concentration changes, stream runoff was substantially increased after harvest, which en- hanced the relative contribution of clear-cuts vs. control forests for downstream mass fluxes. Annual specific runoff of the CC-4 catchment after the harvest (2007-2012) was 518 $( \pm 128) \mathrm{mm}$ whereas the northern control site (NR-7) had a lower average specific discharge of $355( \pm 88) \mathrm{mm}$.

At the BA-1 downstream site, $\mathrm{NO}_{3}^{-}$concentrations showed no statistically significant difference between the periods of 2004-2006 (17.2 $\left.\pm 14.3 \mu \mathrm{g} \mathrm{NL}^{-1} ; n=37\right)$ and 2007-2012 (17.2 $\left.\pm 18.9 \mu \mathrm{g} \mathrm{N} \mathrm{L}^{-1} ; n=151\right)$, even though the upstream area that was clear-cut increased from $2.5 \%$ in 2004 to $11.2 \%$ in 2011 (Fig. 2). At the BA-2 site, where harvests ranged from $4.6 \%$ of the catchment area in 2004 to $17.5 \%$ in 2011, average $\mathrm{NO}_{3}^{-}$concentrations increased modestly ( $t$ test, $p=0.026)$ from $15.9( \pm 9.8 ; n=30) \mu \mathrm{g} \mathrm{NL}^{-1}$ during 2004-2006 to $21.3( \pm 19.1 ; n=151) \mu \mathrm{g} \mathrm{N} \mathrm{L}^{-1}$ during 2007-2012. Similarly, $\mathrm{NH}_{4}^{+}$and DON concentrations at the downstream sites BA-1 and BA-2 increased slightly from 2006 to 2012 (Fig. 3c and d). Also, the contributions of $\mathrm{NH}_{4}^{+}$to the total inorganic $\mathrm{N}$ pool varied at both downstream sites between seasons. On average $\mathrm{NH}_{4}^{+}$accounted for 23 and $18 \%$ during the dormant season, for 45 and $39 \%$ during snowmelt, and 54 and $46 \%$ of the inorganic $\mathrm{N}$ pool during the growing season for BA-1 and BA-2, respectively. Furthermore, $\mathrm{NO}_{3}^{-}$concentrations at these downstream sites, as well as at CC-4 increased continuously throughout the winter period, with the highest values observed just prior to snowmelt. Annual DIN export was generally dominated by $\mathrm{NO}_{3}^{-}$(Table 2) and was the highest from the CC-4 catchment (1.28-1.83 $\left.\mathrm{kg} \mathrm{N} \mathrm{ha}^{-1} \mathrm{yr}^{-1}\right)$, followed by NO-5 $(0.10$ $\left.0.17 \mathrm{~kg} \mathrm{Nha}^{-1} \mathrm{yr}^{-1}\right)$, NR-7 $\left(0.06-0.10 \mathrm{~kg} \mathrm{~N} \mathrm{ha}^{-1} \mathrm{yr}^{-1}\right)$, and RS-3 (0.03-0.07 kg N ha-1 $\left.\mathrm{yr}^{-1}\right)$.

\subsection{Mixing model results}

When modeled concentrations of DON and DIN at BA1 and BA-2 were compared to the measured concentrations, distinct patterns emerged. First, modeled and measured DON concentrations correlated well (relationships: $r^{2}=0.92, p<0.001$ for BA-2 and $r^{2}=0.72, p<0.001$ for 
Table 2. Measured and modeled annual DIN loads per unit catchment area from all six Balsjö catchments during 2008-2011. The percentage of $\mathrm{NO}_{3}^{-}$of the total load is given in brackets.

\begin{tabular}{|c|c|c|c|c|c|c|c|c|}
\hline \multirow[b]{2}{*}{$\begin{array}{l}\text { Site } \\
\text { unit/year }\end{array}$} & \multicolumn{6}{|c|}{ Measured } & \multicolumn{2}{|c|}{ Modeled* } \\
\hline & $\begin{array}{r}\text { BA-1 } \\
\mathrm{mg} \mathrm{N} \mathrm{m}^{-2} \mathrm{yr}^{-1}\end{array}$ & $\begin{array}{r}\text { BA-2 } \\
\mathrm{mg} \mathrm{N} \mathrm{m}^{-2} \mathrm{yr}^{-1}\end{array}$ & $\mathrm{mg} \mathrm{N} \mathrm{m}^{-2} \mathrm{yr}^{-1}$ & $\mathrm{mg} \mathrm{N} \mathrm{m}^{-2} \mathrm{yr}^{-1}$ & $\begin{array}{r}\mathrm{NO}-5 \\
\mathrm{mg} \mathrm{N} \mathrm{m}^{-2} \mathrm{yr}^{-1}\end{array}$ & $\begin{array}{r}\text { NR-7 } \\
\mathrm{mg} \mathrm{N} \mathrm{m}^{-2} \mathrm{yr}^{-1}\end{array}$ & $\begin{array}{r}\text { BA-1 } \\
\mathrm{mg} \mathrm{N} \mathrm{m}^{-2} \mathrm{yr}^{-1}\end{array}$ & $\begin{array}{r}\text { BA-2 } \\
\mathrm{mg} \mathrm{N} \mathrm{m}^{-2} \mathrm{yr}^{-1}\end{array}$ \\
\hline 2008 & $6.1(60 \%)$ & $6.4(66 \%)$ & $3.1(39 \%)$ & $134.8(79 \%)$ & $10.2(42 \%)$ & $6.1(58 \%)$ & $20.6(74 \%)$ & $27.1(76 \%)$ \\
\hline 2009 & $8.0(56 \%)$ & $13.1(72 \%)$ & $7.0(54 \%)$ & $182.9(74 \%)$ & $17.2(54 \%)$ & $9.3(57 \%)$ & $24.5(67 \%)$ & $31.0(68 \%)$ \\
\hline 2010 & $6.5(68 \%)$ & $8.9(70 \%)$ & $3.5(46 \%)$ & $149.1(81 \%)$ & $12.2(68 \%)$ & $7.9(67 \%)$ & $18.9(75 \%)$ & $24.4(77 \%)$ \\
\hline 2011 & $8.2(63 \%)$ & $11.2(63 \%)$ & $3.9(37 \%)$ & $128.3(76 \%)$ & $14.7(69 \%)$ & $9.6(63 \%)$ & $22.1(71 \%)$ & $30.6(73 \%)$ \\
\hline
\end{tabular}

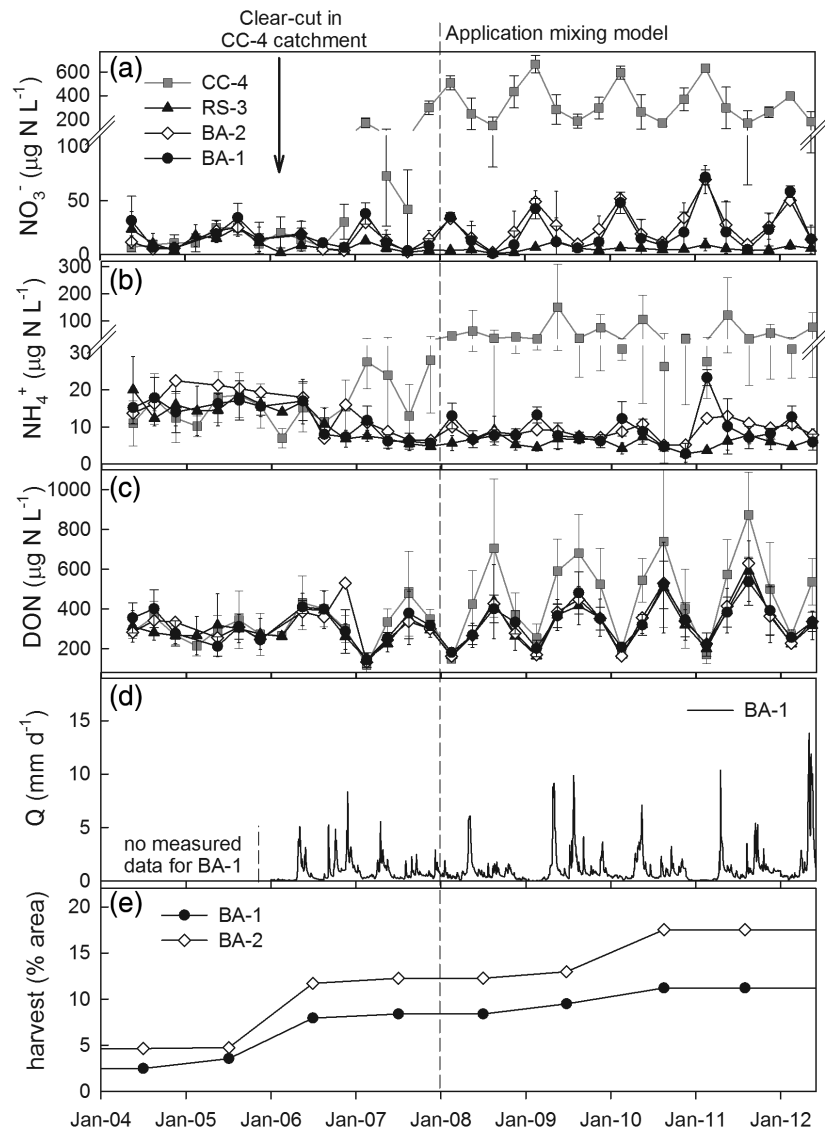

Figure 3. (a) Trimonthly nitrate $\left(\mathrm{NO}_{3}^{-}\right)$concentrations and standard deviations (whiskers) of two first-order streams, the clear-cut catchment (CC-4) and the reference south (RS-3), as well as for two third-order downstream sites BA-2 (size: $8.7 \mathrm{~km}^{2}$ ) and BA-1 (size: $22.9 \mathrm{~km}^{2}$ ). (b) Trimonthly Ammonium $\left(\mathrm{NH}_{4}\right)$ concentrations and (c) concentrations of dissolved organic nitrogen (DON) for the same sites. (d) Discharge at the BA-1 outlet. (e) Satellite derived percentage of catchment area that has been clear-cut harvested since 2001 within BA-2 and BA-1.

BA-1; see also Fig. 4). In contrast, relationships between modeled and measured DIN concentrations were significant, but explained little of the variability $\left(r^{2}=0.23\right.$ for BA-1; $r^{2}=0.31$ for BA-2) with modeled DIN concentrations usually overestimating the measured values (Fig. 4). Similarly, annual modeled DIN exports at the downstream sites were substantially higher than the measured export rates (Table 2).

Modeled DIN removal efficiency calculated as the fraction of DIN that was retained in the system showed a strong seasonal signal (Fig. 5a). $E_{\mathrm{r}}$ values above $75 \%$ were observed just after peak snowmelt, with the exception of the snowmelt of 2012. $E_{\mathrm{r}}$ then remained high $(>75 \%)$ during the summer of 2008, and stayed at intermediate-to-high levels $(>50 \%$ ) during the following summer seasons (Fig. 5a). Towards the end of the growing season, $E_{\mathrm{r}}$ decreased during all years and was followed by another distinct decline, often with values $<40 \%$ throughout the winter (Fig. 5a). Furthermore, no significant relationships between discharge and $E_{\mathrm{r}}$ were observed (Fig. $5 \mathrm{~b}$ and c). DIN removal in the network based on this modeling exercise yielded estimates of net retention $(U)$ for BA-2 that were significantly higher during snowmelt $\left(9.8 \mu \mathrm{g} \mathrm{N} \mathrm{m}^{-2} \mathrm{~min}^{-1}\right)$ than the growing $\left(5.4 \mu \mathrm{g} \mathrm{m}^{-2} \mathrm{~min}^{-1}\right)$ and dormant $\left(5.3 \mu \mathrm{g} \mathrm{N} \mathrm{m}^{-2} \mathrm{~min}^{-1}\right)$ seasons (Fig. 6). Estimates of $U$ for BA-1 were lower, with 2.3, 1.1, and $0.8 \mu \mathrm{g} \mathrm{N} \mathrm{m}^{-2} \mathrm{~min}^{-1}$ for the snowmelt, growing, and dormant season, respectively.

\section{Discussion}

Increases in DIN export in response to forest harvesting are well documented (Jerabkova et al., 2011) and illustrate how terrestrial ecosystem disturbance can control $\mathrm{N}$ mobilization and delivery to small streams. In this study, increases in stream water $\mathrm{NO}_{3}^{-}$concentrations by up to $\sim 15$-fold, together with elevated runoff (Schelker et al., 2013b), resulted in substantial increases in DIN inputs to the fluvial network (Table 2). However, despite obvious effects of forest harvesting on DIN concentrations in first-order streams, only very subtle responses could be detected for the third-order streams within this same network, suggesting that significant DIN retention occurred between the harvested areas in the landscape and downstream monitoring sites.

\subsection{Network patterns in DIN concentration}

At both downstream sites, and the CC-4 clear-cut catchment, concentrations of $\mathrm{NO}_{3}^{-}$were higher during the dormant than growing season (Fig. 3a). Similar seasonal patterns were ob- 

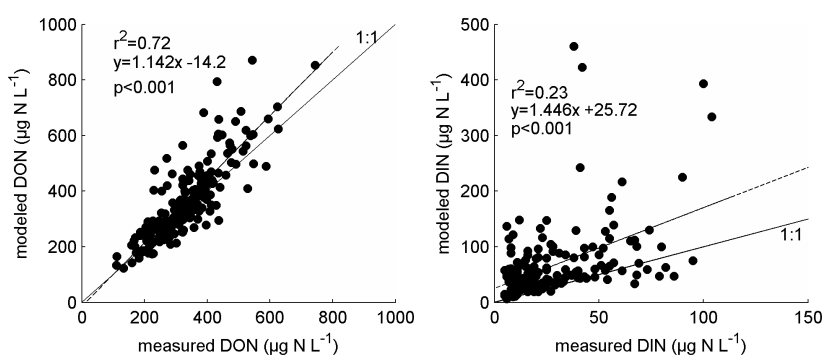

Figure 4. Results of the mass-balance modeling approach for DON (left) and DIN (right) for the downstream site BA-1.

served for $\mathrm{NH}_{4}^{+}$concentrations (Fig. 3b). Overall, such seasonal variation in stream DIN, and specifically stream $\mathrm{NO}_{3}^{-}$ concentration, is common across Sweden (Sponseller et al., 2014; Löfgren et al., 2014) and is thought to reflect seasonal changes in terrestrial $\mathrm{N}$ demand (e.g., Mitchell et al., 1996). In contrast, $\mathrm{NO}_{3}^{-}$concentrations at $\mathrm{RS}-3$ did not show such a seasonal pattern, suggesting particularly low inorganic $\mathrm{N}$ availability and strong $\mathrm{N}$ limitation persisting throughout the year (Stoddard, 1994). This hypothesis is further supported by the fact that average $\mathrm{NO}_{3}^{-}$concentrations at this site decreased significantly by $6.5 \mu \mathrm{g} \mathrm{N} \mathrm{L}-1$ between the period from 2004 to 2006 as compared to 2007 to 2012, indicating that local factors, such as the presence of actively growing forest stands with dense riparian vegetation, resulted in particularly high terrestrial $\mathrm{N}$ demand and thus low stream concentrations at this site.

Temporal variation in $\mathrm{NO}_{3}^{-}$concentrations at the CC-4 clear-cut stream during the dormant season (Fig. 2) was closely correlated with temporal changes in $\mathrm{NO}_{3}^{-}$concentration at downstream sites (Fig. S1 in the Supplement), indicating temporal coherence in concentration change (sensu Kling et al., 2000) across the stream network during this period. In contrast, temporal changes in upstream and downstream $\mathrm{NO}_{3}^{-}$concentrations were not correlated during the growing season (Fig. S1 in the Supplement). Overall, these observations suggest (i) a common seasonal control where $\mathrm{NO}_{3}^{-}$retention in most catchments declines throughout the dormant season, (ii) that enhanced upstream inputs of $\mathrm{NO}_{3}^{-}$in headwaters are translated downstream during the dormant season, and (iii) that temporal nutrient dynamics at upstream and downstream reaches become uncoupled during the spring and the summer growing season.

\subsection{Comparison of modeled and measured streamwater $\mathbf{N}$}

We found a close correspondence between modeled and measured DON concentrations, similar to relationships previously observed for dissolved organic carbon (Schelker et al., 2014), as well as the two conservative tracers, dissolved silica and chloride (Fig. 2). This close relationship between observed and predicted concentrations is indicative of an ap-

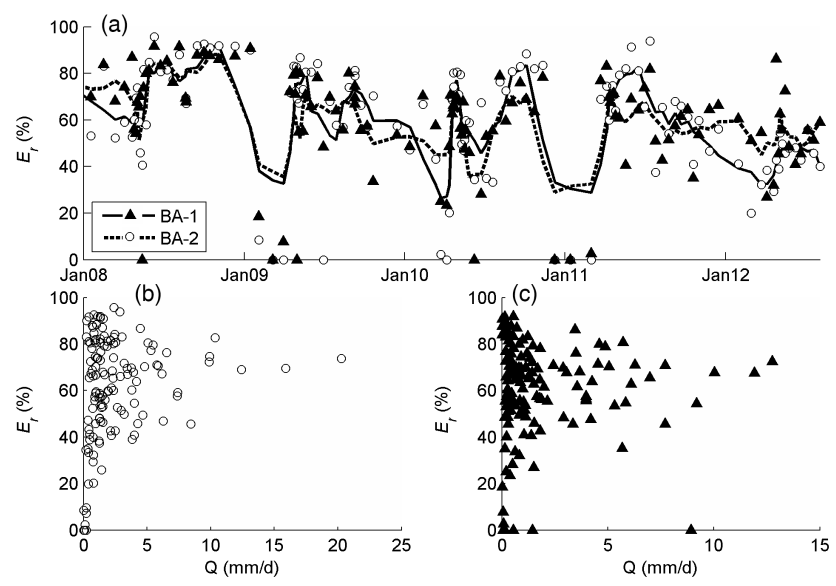

Figure 5. (a) Seasonal variation in $\mathrm{NO}_{3}^{-}$removal efficiency $\left(E_{\mathrm{r}}\right)$, for the two downstream sites BA-1 and BA-2; lines represent moving averages with $n=5$. (b) $E_{\mathrm{r}}$ vs. $Q$ for the BA-2 catchment outlet and (c) $E_{\mathrm{r}}$ vs. $Q$ for the BA-1 site.

proximately conservative downstream transport of DON in the network. These patterns provide additional support for the applicability of our mixing model in this landscape, and they are consistent with the idea that bulk DON is composed primarily of organic compounds of low bioavailability that are exported from landscapes without strong biotic controls (Hedin et al., 1995). For this reason, DON also often represents the major loss vector for $\mathrm{N}$ in catchments that are not subject to large anthropogenic inputs of DIN (Perakis, 2002; Kortelainen et al., 1997). Importantly, DON exports at CC4 also increased following harvesting (Fig. 3d), a response that has been reported elsewhere in Scandinavia (Smolander et al., 2001). While this response was more subtle than that observed for DIN, the conservative behavior of DON in the stream network suggests that it likely represents an important and largely unappreciated source of terrestrially derived $\mathrm{N}$ to downstream receiving systems (Rosén et al., 1996).

In contrast to DON, we observed generally poor relationships between measured and modeled DIN concentrations at BA-1 and BA-2 (Fig. 4; data for BA-2 not shown). This mismatch most likely results from seasonal $\mathrm{NO}_{3}^{-}$removal, a pattern illustrated by the temporal variation of $E_{\mathrm{r}}$ for both sites (Fig. 5). Low dormant season values of $E_{\mathrm{r}}$ suggest an ostensibly weak $\mathrm{NO}_{3}^{-}$demand in cold, snow-covered streams and thus low strength of the biological sink within the fluvial network. During this period a large fraction of $\mathrm{NO}_{3}^{-}$entering the stream network was also exported downstream, which is exemplified by the upstream-downstream synchrony in nutrient concentrations observed during this period (S1) and the few wintertime occasions where $E_{\mathrm{r}}$ was near zero. These occasions suggest that either (i) all $\mathrm{NO}_{3}^{-}$was transported downstream (e.g., that $\mathrm{NO}_{3}^{-}$transport was conservative) or (ii) that the downstream reaches of the stream network acted as source areas of $\mathrm{NO}_{3}^{-}$. The latter has been previously hy- 


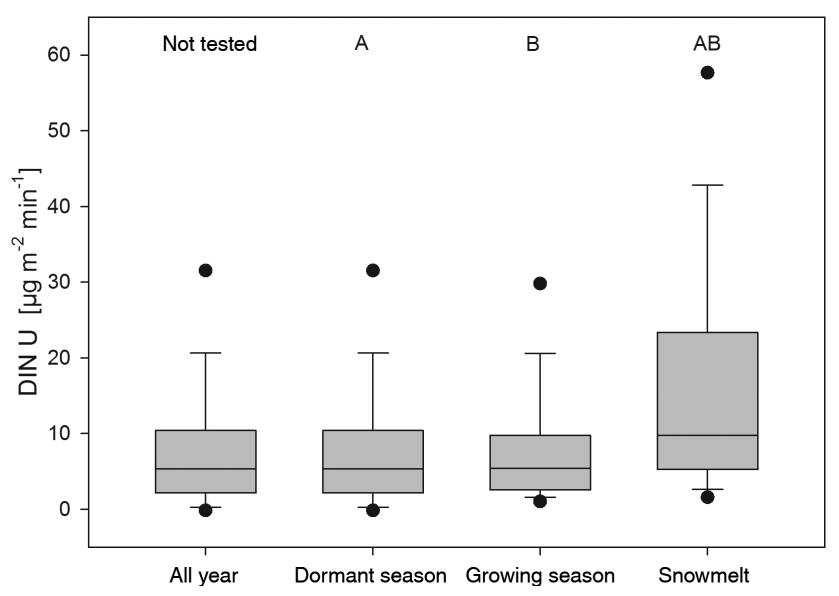

Figure 6. Boxplot of the seasonal differences in net $\mathrm{NO}_{3}^{-}$uptake rates $(U)$ per unit stream area during 2008-2011 in the BA-2 catchment. Solid lines represent median values, boxes the 25 th to 75 th percentile range, whiskers the 90th to 10th percentiles and dots the 95th and the 5th percentiles. Pairs of letters indicate highly significant differences between seasons $(p<0.001$; Mann-Whitney rank sum test). Values for BA-1 site are generally lower, but show similar seasonal differences.

pothesized to cause discrepancies of reach-scale $\mathrm{N}$ mass balances (von Schiller et al., 2011).

Interestingly, $E_{\mathrm{r}}$ did not show a direct dependence on stream discharge at any of the downstream sites (Fig. 5), suggesting that $\mathrm{N}$ demand rather than flow and/or transient storage (Ensign and Doyle, 2006) were controlling DIN removal in the fluvial network. In addition, high removal efficiencies during spring and summer had substantial effects on overall annual net DIN uptake as estimated by the difference of modeled and measured annual DIN exports. These estimates $( \pm \mathrm{SD})$ showed that $67( \pm 3)$ and $65( \pm 8) \%$, respectively, of the DIN inputs to the BA-1 and BA-2 catchments were removed before reaching these monitoring stations (Table 2). These estimates are of course sensitive to how the clear-cut EM was represented in the mixing model. For example, if we assume that all clear-cut areas would follow the less pronounced concentration response of NO5 then the average annual DIN removal would sum to $22 \%$ for BA-1 and only $9 \%$ for BA-2, with the latter even acting as a source of DIN $(+2 \%)$ during 1 year (2009). However, we consider this extreme scenario unrealistic for at least two reasons. First, several harvests in the drainage area of the stream network, but outside the experimental harvest of NO-5 and CC-4, showed substantial disturbance of riparian soils, for example from multiple stream crossings of forestry machines and from wind throw of trees in the riparian zone. These disturbances will likely result in a concentration response closer to that of CC-4, than that of NO-5. Second, the CC-4 clear-cut is located within the BA-2 drainage area and represents an important fraction of the harvested area within this catchment (Table 1). Thus, the CC-4 harvest would itself not be correctly represented in this modeling scenario. Indeed, this omission gives rise to the hypothetical gain of DIN within BA-2 in 2009, which suggests a missing source of DIN in the catchment under this scenario. Regardless, further research characterizing the spatial and temporal variation in DIN runoff responses following harvests would lend more confidence to estimates of $\mathrm{N}$ removal based on this massbalance approach.

Our estimates of net DIN removal within this stream network suggest that, during most periods, reasonable levels of in-stream activity (i.e., net uptake) could account for the discrepancy between measured and modeled fluxes at downstream stations. Assuming that all DIN retention was occurring within the stream channels, median values and interquartile ranges (25th to 75 th percentile) of $U$ for the BA-2 catchment were $5.4(2.2 ; 10.4) \mu \mathrm{g} \mathrm{N} \mathrm{m}{ }^{-2} \mathrm{~min}^{-1}$ for the entire year. Even lower rates of in-stream uptake would be sufficient to account for the differences between modeled and observed DIN at BA-1. While these values fall well within the range of net uptake estimates made elsewhere for small streams (Bernhardt et al., 2003; Roberts and Mulholland, 2007; von Schiller et al., 2011), further efforts to directly quantify rates of DIN removal in boreal streams are warranted.

As with $E_{\mathrm{r}}$, estimates of $U$ were significantly higher during snowmelt as compared to the growing season and, interestingly, there was no significant difference in median values between growing and dormant seasons (Fig. 6). While other recent studies indicate the potential for high rates of nutrient uptake during the snowmelt period (Hall et al., 2009), these seasonal comparisons should be made with some caution as our estimates of net areal uptake do not account for losses that occur to the outside of the stream, for example, in riparian habitats, embedded wetlands, lakes, and/or into deep groundwater aquifers. In particular, embedded wetlands and small lakes upstream of BA-1 and BA-2 (Table 1) are common features of boreal landscapes and may play a particularly important role in $\mathrm{N}$ removal at the scale of stream networks. Overall, these seasonal removal estimates are surprising, and more work is required to understand the hydrological and biogeochemical mechanisms underpinning these patterns.

Important mechanisms that control DIN removal from stream water during the growing season are biological uptake by riparian vegetation (Sabater et al., 2000) and immobilization by in-stream autotrophs and heterotrophs. These instream sinks may also change in response to forest harvesting, for example, if elevated light conditions foster increased photoautotrophic production (Bernhardt and Likens, 2004). Indication that such increased in-stream DIN demand during the growing season may also be present in the Balsjö stream network is given by $\sim 30$-fold greater summertime accumulation of algal biomass (chlorophyll $a$ ) onto ceramic tiles in the CC-4 stream as compared to RS-3 (R. Sponseller, unpublished data). Similarly, a recent survey of boreal streams (including CC-4 and RS-3) showed that heterotrophic biofilm 
respiration can be strongly $\mathrm{N}$ limited and reported the highest rates of biofilm respiration at the clear-cut stream of CC4 (Burrows et al., 2015). However, immobilization by autotrophs and heterotrophs does not necessarily result in permanent removal of $\mathrm{N}$ from the stream, as a large portion of this nutrient pool may be rapidly recycled as biofilm materials decay (Tank et al., 2000). Nevertheless, these observations highlight the importance of $\mathrm{N}$ as a limiting factor in northern, boreal streams and support the idea that these systems may respond strongly to elevated $\mathrm{N}$ loading following harvests.

An additional process that may account for the permanent removal of $\mathrm{NO}_{3}^{-}$observed in this study and thus for the seasonal differences in $U$ is denitrification (Mulholland et al., 2008). Environments that have been observed to favor the direct conversion of $\mathrm{NO}_{3}^{-}$to gaseous $\mathrm{N}$ by denitrification are (i) stream biofilms (Teissier et al., 2007), (ii) stream hyporheic zones (Harvey et al., 2013), and (iii) riparian sediments (Starr and Gillham, 1993). Furthermore, experimental studies have demonstrated that denitrification is often found to be co-dependent on terrestrial $\mathrm{NO}_{3}^{-}$inputs and bioavailable dissolved organic matter (DOM) as an electron donor (Baker et al., 1999). More specifically, hot moments of denitrification, that is, periods of disproportionally high and short-lived $\mathrm{NO}_{3}^{-}$demand, can be generated by experimental additions of labile DOM (Zarnetske et al., 2011). Such enhanced demand in response to labile DOM inputs has further been shown to regulate uptake rates in streams (Bernhardt and Likens, 2002) and hyporheic sediments (Sobczak et al., 2003).

Transferring this well-established process knowledge from the reach scale to the network scale suggests that $\mathrm{NO}_{3}^{-}$removal at the landscape scale may be dependent on a sufficient supply of labile DOM to all stream reaches within the network that are located downstream of harvests. Bulk DOM contributions in Balsjö have been observed to increase as a response to harvesting (Schelker et al., 2012) and other studies in boreal headwater streams have shown that terrestrially derived, low molecular weight DOM (e.g., free amino acids, carboxylic acids, and carbohydrates) can achieve high concentrations during the spring snowmelt (Berggren et al., 2009). These terrestrial inputs have further been suggested to support the microbial $\mathrm{C}$ demand of downstream aquatic ecosystems during a time frame of days to weeks following the spring freshet (Berggren et al., 2009) - a period when $E_{\mathrm{r}}$ was also the highest in our study. Thus, we hypothesize that limitation of heterotrophic processes, such as denitrification and immobilization, occurs via restricted supply of bioavailable DOM from terrestrial sources during the dormant season as a plausible mechanism that inhibits DIN removal at the network scale. In turn, the restricted supply of DIN relative to bioavailable $\mathrm{C}$ during the other times of the year would then limit heterotrophic activities and foster efficient $\mathrm{N}$ removal in the network - a coupling that has been suggested previously for boreal streams (Berggren et al., 2007).
In summary our work agrees with earlier studies in that terrestrial ecosystem disturbance enhances DIN mobilization into first-order streams (Likens et al., 1970) and that such increased $\mathrm{NO}_{3}^{-}$concentrations can potentially be transferred downstream during some portions of the years (Alexander et al., 2007). The hypothesis that stream and riparian processing of $\mathrm{NO}_{3}^{-}$may dampen the effect at downstream sites (Bernhardt et al., 2003) was supported during the snowmelt, as well as during the growing season when rates of biological activity and supply of bioavailable $\mathrm{C}$ are likely to be high. During the dormant season, however, results suggest that limited DIN uptake rates constrain the potential for DIN removal within the fluvial network. Considering the measures to increase forest production of either increased fertilization or shorter forest rotations (Egnell et al., 2011), we argue that both are likely to increase downstream export of DIN, provided that instream removal rates remain the same as under current conditions. More specifically, shorter forest rotations would increase the frequency of disturbance due to harvesting and thus the periods where elevated leaching may occur. Similarly, increased fertilization may enhance the risk of DIN leakage into surface waters particularly during the dormant season (Binkley et al., 1999) when the biological demand for DIN is low within boreal stream networks.

\section{The Supplement related to this article is available online at doi:10.5194/bg-13-1-2016-supplement.}

Acknowledgements. Funding for this work was provided by the Swedish Environmental Protection Agency, EU Life (Forest for Water), CMF, Future Forests, and the Formas (ForWater). We thank Peder Blomkvist, Viktor Sjöblom, and Ida Taberman for help in the field and the laboratory.

Edited by: T. J. Battin

\section{References}

Aber, J. D., Ollinger, S. V., Driscoll, C. T., Likens, G. E., Holmes, R. T., Freuder, R. J., and Goodale, C. L.: Inorganic nitrogen losses from a forested ecosystem in responseto physical, chemical, biotic, and climatic perturbations, Ecosystems, 5, 0648-0658, doi:10.1007/s10021-002-0203-8, 2002.

Alexander, R., Boyer, E. W., Smith, R. A., Schwarz, G. E., and Moore, R. B.: The role of headwater streams in downstream water quality1, JAWRA Journal of the American Water Resources Association, 43, 41-59, doi:10.1111/j.1752-1688.2007.00005.x, 2007.

Alexander, R., Böhlke, J., Boyer, E., David, M., Harvey, J., Mulholland, P., Seitzinger, S., Tobias, C., Tonitto, C., and Wollheim, W.: Dynamic modeling of nitrogen losses in river networks unravels the coupled effects of hydrological and biogeochemical pro- 
cesses, Biogeochemistry, 93, 91-116, doi:10.1007/s10533-0089274-8, 2009.

Andréassian, V.: Waters and forests: From historical controversy to scientific debate, J. Hydrol., 291, 1-27, 2004.

Baker, M. A., Dahm, C. N., and Valett, H. M.: Acetate retention and metabolism in the hyporheic zone of a mountain stream, Limnol. Oceanogr., 44, 1530-1539, 1999.

Berggren, M., Laudon, H., and Jansson, M.: Landscape regulation of bacterial growth efficiency in boreal freshwaters, Global Biogeochem. Cy., 21, GB4002, doi:10.1029/2006GB002844, 2007.

Berggren, M., Laudon, H., Haei, M., Strom, L., and Jansson, M.: Efficient aquatic bacterial metabolism of dissolved low-molecularweight compounds from terrestrial sources, ISME J., 4, 408-416, 2009.

Bernhardt, E. S. and Likens, G. E.: Dissolved organic carbon enrichment alters nitrogen dynamics in a forest stream, Ecology, 83, 1689-1700, 2002.

Bernhardt, E. S. and Likens, G. E.: Controls on periphyton biomass in heterotrophic streams, Freshwater. Biol., 49, 14-27, doi:10.1046/j.1365-2426.2003.01161.x, 2004.

Bernhardt, E. S., Likens, G. E., Buso, D. C., and Driscoll, C. T.: In-stream uptake dampens effects of major forest disturbance on watershed nitrogen export, P. Natl. Acad. Sci., 100, 1030410308, doi:10.1073/pnas.1233676100, 2003.

Binkley, D. and Brown, T. C.: Forest practices as nonpoint sources of pollution in north america, JAWRA Journal of the American Water Resources Association, 29, 729-740, doi:10.1111/j.17521688.1993.tb03233.x, 1993.

Binkley, D., Burnham, H., and Lee Allen, H.: Water quality impacts of forest fertilization with nitrogen and phosphorus, Forest Ecol. Manage., 121, 191-213, doi:10.1016/S0378-1127(98)00549-0, 1999.

Bishop, K., Seibert, J., Köhler, S., and Laudon, H.: Resolving the double paradox of rapidly mobilized old water with highly variable responses in runoff chemistry, Hydrol. Process., 18, 185189, 2004.

Boring, L. R., Monk, C. D., and Swank, W. T.: Early regeneration of a clear-cut southern appalachian forest, Ecology, 62, 1244-1253, doi: 10.2307/1937289, 1981.

Burrows, R. M., Hotchkiss, E. R., Jonsson, M., Laudon, H., McKie, B. G., and Sponseller, R. A.: Nitrogen limitation of heterotrophic biofilms in boreal streams, Freshwater. Biol., 60, 1237-1251, doi:10.1111/fwb.12549, 2015.

Egnell, G., Laudon, H., and Rosvall, O.: Perspectives on the potential contribution of swedish forests to renewable energy targets in europe, Forests, 2, 578-589, 2011.

Ensign, S. H. and Doyle, M. W.: Nutrient spiraling in streams and river networks, J. Geophys. Res.-Biogeo., 111, G04009, doi:10.1029/2005jg000114, 2006.

Futter, M. N., Ring, E., Högbom, L., Entenmann, S., and Bishop, K. H.: Consequences of nitrate leaching following stem-only harvesting of swedish forests are dependent on spatial scale, Environ. Pollut., 158, 3552-3559, 2010.

Groffman, P. M., Boulware, N. J., Zipperer, W. C., Pouyat, R. V., Band, L. E., and Colosimo, M. F.: Soil nitrogen cycle processes in urban riparian zones, Environ. Sci. Technol., 36, 4547-4552, 2002 .
Hall, R. O., Baker, M. A., Arp, C. D., and Kocha, B. J.: Hydrologic control of nitrogen removal, storage, and export in a mountain stream, Limnol. Oceanogr., 54, 2128-2142, 2009.

Harvey, J. W., Böhlke, J. K., Voytek, M. A., Scott, D., and Tobias, C. R.: Hyporheic zone denitrification: Controls on effective reaction depth and contribution to whole-stream mass balance, Water Resour. Res., 49, 6298-6316, doi:10.1002/wrcr.20492, 2013.

Hedin, L. O., Armesto, J. J., and Johnson, A. H.: Patterns of nutrient loss from unpolluted, old-growth temperate forests: Evaluation of biogeochemical theory, Ecology, 76, 493-509, doi:10.2307/1941208, 1995.

Helton, A. M., Poole, G. C., Meyer, J. L., Wollheim, W. M., Peterson, B. J., Mulholland, P. J., Bernhardt, E. S., Stanford, J. A., Arango, C., Ashkenas, L. R., Cooper, L. W., Dodds, W. K., Gregory, S. V., Hall Jr., R. O., Hamilton, S. K., Johnson, S. L., McDowell, W. H., Potter, J. D., Tank, J. L., Thomas, S. M., Valett, H. M., Webster, J. R., and Zeglin, L.: Thinking outside the channel: Modeling nitrogen cycling in networked river ecosystems, Front. Ecol. Environ., 9, 229-238, 2011.

Hill, A. R.: Nitrogen dynamics of storm runoff in the riparian zone of a forested watershed, Biogeochemistry, 20, 19-44, 1993.

Högberg, P., Fan, H. B., Quist, M., Binkley, D., and Tamm, C. O.: Tree growth and soil acidification in response to 30 years of experimental nitrogen loading on boreal forest, Glob. Change Biol., 12, 489-499, doi:10.1111/j.1365-2486.2006.01102.x, 2006.

Holmes, W. E. and Zak, D. R.: Soil microbial control of nitrogen loss following clear-cut harvest in northern hardwood ecosystems, Ecol. Appl., 9, 202-215, doi:10.1890/10510761(1999)009[0202:smconl]2.0.co;2, 1999.

Hornbeck, J. W., Martin, C. W., and Eagar, C.: Summary of water yield experiments at hubbard brook experimental forest, new hampshire, Can. J. For. Res., 27, 2043-2052, 1997.

Houlton, B. Z., Driscoll, C. T., Fahey, T. J., Likens, G. E., Groffman, P. M., Bernhardt, E. S., and Buso, D. C.: Nitrogen dynamics in ice storm-damaged forest ecosystems: Implications for nitrogen limitation theory, Ecosystems, 6, 431-443, doi:10.1007/s10021002-0198-1, 2003.

Jansson, M., Bergström, A. K., Drakare, S., and Blomqvist, P.: Nutrient limitation of bacterioplankton and phytoplankton in humic lakes in northern sweden, Freshwater. Biol., 46, 653-666, 2001.

Jerabkova, L., Prescott, C. E., Titus, B. D., Hope, G. D., and Walters, M. B.: A meta-analysis of the effects of clearcut and variable-retention harvesting on soil nitrogen fluxes in boreal and temperate forests, Can. J. Forest Res., 41, 1852-1870, doi:10.1139/x11-087, 2011.

Kling, G. W., Kipphut, G. W., Miller, M. M., and O'Brien, W. J.: Integration of lakes and streams in a landscape perspective: The importance of material processing on spatial patterns and temporal coherence, Freshwater. Biol., 43, 477-497, 2000.

Kortelainen, P., Saukkonen, S., and Mattsson, T.: Leaching of nitrogen from forested catchments in finland, Global Biogeochem. Cy., 11, 627-638, doi:10.1029/97gb01961, 1997.

Kreutzweiser, D. P., Hazlett, P. W., and Gunn, J. M.: Logging impacts on the biogeochemistry of boreal forest soils and nutrient export to aquatic systems: A review, Environ. Rev., 16, 157-179, doi:10.1139/A08-006, 2008.

Laudon, H., Berggren, M., Agren, A., Buffam, I., Bishop, K., Grabs, T., Jansson, M., and Kohler, S.: Patterns and dynamics of dissolved organic carbon (doc) in boreal streams: The role of 
processes, connectivity, and scaling, Ecosystems, 14, 880-893, doi:10.1007/s10021-011-9452-8, 2011.

Laurén, A., Finér, L., Koivusalo, H., Kokkonen, T., Karvonen, T., Kellomäki, S., Mannerkoski, H., and Ahtiainen, M.: Water and nitrogen processes along a typical water flowpath and streamwater exports from a forested catchment and changes after clearcutting: a modelling study, Hydrol. Earth Syst. Sci., 9, 657-674, doi:10.5194/hess-9-657-2005, 2005.

Likens, G. E. and Bormann, F. H.: Biogeochemistry of a forested ecosystem, Springer-Verlag New York, Inc., 1995.

Likens, G. E., Bormann, F. H., Johnson, N. M., Fisher, D. W., and Pierce, R. S.: Effects of forest cutting and herbicide treatment on nutrient budgets in the hubbard brook watershed-ecosystem, Ecol. Monogr., 40, 23-47, doi:10.2307/1942440, 1970.

Löfgren, S., Ring, E., von Brömssen, C., Sørensen, R., and Högbom, L.: Short-term effects of clear-cutting on the water chemistry of two boreal streams in northern sweden: A paired catchment study, Ambio, 38, 347-356, doi:10.1579/0044-744738.7.347, 2009.

Löfgren, S., Fröberg, M., Yu, J., Nisell, J., and Ranneby, B.: Water chemistry in 179 randomly selected swedish headwater streams related to forest production, clear-felling and climate, Environ. Monit. Assess., 186, 8907-8928, doi:10.1007/s10661-014-40545, 2014.

Martin, C. W., Hornbeck, J. W., Likens, G. E., and Buso, D. C.: Impacts of intensive harvesting on hydrology and nutrient dynamics of northern hardwood forests, Can. J. Fish. Aquat. Sci., 57, 1929, doi:10.1139/f00-106, 2000.

McClain, M. E., Boyer, E. W., Dent, C. L., Gergel, S. E., Grimm, N. B., Groffman, P. M., Hart, S. C., Harvey, J. W., Johnston, C. A., Mayorga, E., McDowell, W. H., and Pinay, G.: Biogeochemical hot spots and hot moments at the interface of terrestrial and aquatic ecosystems, Ecosystems, 6, 301-312, 2003.

Mitchell, M. J., Driscoll, C. T., Kahl, J. S., Murdoch, P. S., and Pardo, L. H.: Climatic control of nitrate loss from forested watersheds in the northeast united states, Environ. Sci. Technol., 30, 2609-2612, doi:10.1021/es9600237, 1996.

Mulholland, P. J., Helton, A. M., Poole, G. C., Hall, R. O., Hamilton, S. K., Peterson, B. J., Tank, J. L., Ashkenas, L. R., Cooper, L. W., Dahm, C. N., Dodds, W. K., Findlay, S. E. G., Gregory, S. V., Grimm, N. B., Johnson, S. L., McDowell, W. H., Meyer, J. L., Valett, H. M., Webster, J. R., Arango, C. P., Beaulieu, J. J., Bernot, M. J., Burgin, A. J., Crenshaw, C. L., Johnson, L. T., Niederlehner, B. R., O'Brien, J. M., Potter, J. D., Sheibley, R. W., Sobota, D. J., and Thomas, S. M.: Stream denitrification across biomes and its response to anthropogenic nitrate loading, Nature, 452, 202-205, doi:10.1038/nature06686, 2008.

Ocampo, C. J., Oldham, C. E., and Sivapalan, M.: Nitrate attenuation in agricultural catchments: Shifting balances between transport and reaction, Water Resour. Res., 42, W01408, doi:10.1029/2004WR003773, 2006.

Palviainen, M., Finér, L., Laiho, R., Shorohova, E., Kapitsa, E., and Vanha-Majamaa, I.: Carbon and nitrogen release from decomposing scots pine, norway spruce and silver birch stumps, Forest Ecol. Manage., 259, 390-398, doi:10.1016/j.foreco.2009.10.034, 2010.

Perakis, S. S.: Nutrient limitation, hydrology and watershed nitrogen loss, Hydrol. Process., 16, 3507-3511, doi:10.1002/hyp.5078, 2002.
Pinay, G., Black, V., Planty-Tabacchi, A., Gumiero, B., and Decamps, H.: Geomorphic control of denitrification in large river floodplain soils, Biogeochemistry, 50, 163-182, 2000.

Ranalli, A. J. and Macalady, D. L.: The importance of the riparian zone and in-stream processes in nitrate attenuation in undisturbed and agricultural watersheds - a review of the scientific literature, J. Hydrol., 389, 406-415, 2010.

Riscassi, A. L. and Scanlon, T. M.: Nitrate variability in hydrological flow paths for three mid-appalachian forested watersheds following a large-scale defoliation, J. Geophys. Res.-Biogeo., 114, G02009, doi:10.1029/2008jg000860, 2009.

Roberts, B. J. and Mulholland, P. J.: Instream biotic control on nutrient biogeochemistry in a forested stream, west fork of walker branch, J. Geophys. Res., 112, G04002, doi:10.1029/2007JG000422, 2007.

Rosén, K., Aronson, J.-A., and Eriksson, H. M.: Effects of clearcutting on streamwater quality in forest catchments in central sweden, Forest Ecol. Manage., 83, 237-244, doi:10.1016/03781127(96)03718-8, 1996.

Sabater, F., Butturini, A., Martí, E., Muñoz, I., Romaní, A., Wray, J., and Sabater, S.: Effects of riparian vegetation removal on nutrient retention in a mediterranean stream, J. N. Am. Benthol. Soc., 19, 609-620, 2000.

Scanlon, T. M., Ingram, S. M., and Riscassi, A. L.: Terrestrial and instream influences on the spatial variability of nitrate in a forested headwater catchment, J. Geophys. Res.-Biogeo., 115, G02022, doi:10.1029/2009JG001091, 2010.

Schelker, J., Eklöf, K., Bishop, K., and Laudon, H.: Effects of forestry operations on dissolved organic carbon concentrations and export in boreal first-order streams, J. Geophys. Res., 117, G01011, doi:10.1029/2011jg001827, 2012.

Schelker, J., Grabs, T., Bishop, K., and Laudon, H.: Drivers of increased organic carbon concentrations in stream water following forest disturbance: Separating effects of changes in flow pathways and soil warming, J. Geophys. Res.-Biogeo., 118, 18141827, doi:10.1002/2013jg002309, 2013 a.

Schelker, J., Kuglerová, L., Eklöf, K., Bishop, K., and Laudon, H.: Hydrological effects of clear-cutting in a boreal forest - snowpack dynamics, snowmelt and streamflow responses, J. Hydrol., 484, 105-114, doi:10.1016/j.jhydrol.2013.01.015, 2013b.

Schelker, J., Öhman, K., Löfgren, S., and Laudon, H.: Scaling of increased dissolved organic carbon inputs by forest clearcutting - what arrives downstream?, J. Hydrol., 508, 299-306, doi:10.1016/j.jhydrol.2013.09.056, 2014.

Seitzinger, S., Harrison, J. A., Böhlke, J. K., Bouwman, A. F., Lowrance, R., Peterson, B., Tobias, C., and Drecht, G. V.: Denitrification across landscapes and waterscapes: A synthesis, Ecol. Appl., 16, 2064-2090, doi:10.1890/10510761(2006)016[2064:dalawa]2.0.co;2, 2006.

Smolander, A., Kitunen, V., and Mälkönen, E.: Dissolved soil organic nitrogen and carbon in a norway spruce stand and an adjacent clear-cut, Biol. Fert. Soils, 33, 190-196, 2001.

Sobczak, W. V., Findlay, S., and Dye, S.: Relationships between doc bioavailability and nitrate removal in an upland stream: An experimental approach, Biogeochemistry, 62, 309-327, 2003.

Sponseller, R. A., Temnerud, J., Bishop, K., and Laudon, H.: Patterns and drivers of riverine nitrogen $(\mathrm{N})$ across alpine, subarctic, and boreal Sweden, Biogeochemistry, 120, 105-120, doi:10.1007/s10533-014-9984-z, 2014. 
Starr, R. C. and Gillham, R. W.: Denitrification and organic carbon availability in two aquifers, Ground Water, 31, 934-947, doi:10.1111/j.1745-6584.1993.tb00867.x, 1993.

Stoddard, J. L.: Long-term changes in watershed retention of nitrogen, in: Environmental chemistry of lakes and reservoirs, edited by: Baker, L. A., Advances in chemistry, 237, American Chemical Society, Washington D.C., 223-284, 1994.

Swank, W. T. and Vose, J. M.: Long-term nitrogen dynamics of coweeta forested watersheds in the southeastern united states of america, Global Biogeochem. Cy., 11, 657-671, doi:10.1029/97gb01752, 1997.

Tank, J. L., Meyer, J. L., Sanzone, D. M., Mulholland, P. J., Webster, J. R., Peterson, B. J., Wollheim, W. M., and Leonard, N. E.: Analysis of nitrogen cycling in a forest stream during autumn using a 15n-tracer addition, Limnol. Oceanogr., 45, 1013-1029, 2000.

Teissier, S., Torre, M., Delmas, F., and Garabétian, F.: Detailing biogeochemical $\mathrm{n}$ budgets in riverine epilithic biofilms, J. N. Am. Benthol. Soc., 26, 178-190, doi:10.1899/08873593(2007)26[178:dbnbir]2.0.co;2, 2007.

Valett, H., Thomas, S., Mulholland, P., Webster, J., Dahm, C., Fellows, C. S., Crenshaw, C., and Peterson, C.: Endogenous and exogenous control of ecosystem function: $\mathrm{N}$ cycling in headwater streams, Ecology, 89, 3515-3527, 2008.

Vidon, P. G. F. and Hill, A. R.: Landscape controls on nitrate removal in stream riparian zones, Water Resour. Res., 40, W03201, doi:10.1029/2003wr002473, 2004.
Vitousek, P. M., Gosz, J. R., Grier, C. C., Melillo, J. M., Reiners, W. A., and Todd, R. L.: Nitrate losses from disturbed ecosystems, Science, 204, 469-474, doi:10.1126/science.204.4392.469, 1979.

von Schiller, D., Bernal, S., and Martí, E.: Technical Note: A comparison of two empirical approaches to estimate in-stream net nutrient uptake, Biogeosciences, 8, 875-882, doi:10.5194/bg-8875-2011, 2011.

Weller, D. E., Baker, M. E., and Jordan, T. E.: Effects of riparian buffers on nitrate concentrations in watershed discharges: New models and management implications, Ecol. Appl., 21, 16791695, 2011.

Wollheim, W. M., Vörösmarty, C. J., Peterson, B. J., Seitzinger, S. P., and Hopkinson, C. S.: Relationship between river size and nutrient removal, Geophys. Res. Lett., 33, L06410, doi:10.1029/2006GL025845, 2006.

Worrall, F., Burt, T. P., Howden, N. J. K., and Whelan, M. J.: The fluvial flux of nitrate from the uk terrestrial biosphere - an estimate of national-scale in-stream nitrate loss using an export coefficient model, J. Hydrol., 414-415, 31-39, doi:10.1016/j.jhydrol.2011.09.020, 2012.

Zarnetske, J. P., Haggerty, R., Wondzell, S. M., and Baker, M. A.: Labile dissolved organic carbon supply limits hyporheic denitrification, J. Geophys. Res.-Biogeo., 116, G04036, doi:10.1029/2011jg001730, 2011. 